\title{
Estimation of the Efficiency of Ammonia Oxidation in Anolyte of Two-Chamber Electrolyzer
}

\author{
Mykola Gomelya ${ }^{1}$, Tetyana Shabliy ${ }^{1 *}$, Iaroslav Radovenchyk ${ }^{1}$, \\ Tetyana Overchenko', Vita Halysh¹
}

${ }^{1}$ Department of Ecology and Technology of Plant Polymers, Faculty of Chemical Engineering, Igor Sikorsky Kyiv Polytechnic Institute, Peremogy Avenu 37/4, 03056 Kyiv, Ukraine

*Corresponding author's e-mail: dsts1@ukr.net

\begin{abstract}
In this study, the processes of electrochemical oxidation of ammonia in a two-chamber electrolyzer with anion exchange membrane MA-41 were investigated. An estimation of the efficiency of the process of oxidation of ammonia, depending on the chemical composition of the initial solution of anolyte and catholyte, current density and time of electrolysis was carried out. It was shown that the oxidation of ammonia in the anode chamber passes quickly and is accompanied by a significant decrease in $\mathrm{pH}$ due to the formation of nitrogen dioxide and nitrates. At the same time, the current output and the electrical conductivity of the dilute solutions was rather low. The effect of chlorides on the process of electrolysis was investigated. It was shown that the presence of chlorides in the anolyte catalyzes the processes of oxidation of ammonia. An increase in the concentration of chlorides in the anolyte increases output and reduces electricity consumption. The presence of chlorides in the catholyte does not accelerate oxidation. The presence of sulfates, both in the anolyte and in the catholyte, slows down the process of oxidation of ammonia as a result of the oxidation of sulfates to persulfates, which are quite passive to ammonium ions. At the same time, electricity consumption increases.
\end{abstract}

Keywords: ammonia, electrolysis, anolyte, catholyte, anion exchange membrane MA-41

\section{INTRODUCTION}

Huge volumes of domestic and industrial waste water are the reason for the pollution of water bodies with various nitrogen-containing organic compounds. This is due to the operation of the livestock farms; to the application of ammonium fertilizers in farmland; operation of municipal waste water treatment facilities; operation of enterprises of chemical, food and forest industry. During the decomposition of such contaminants, ammonia is formed, which serves as a source of ammonium ions formation.

In Ukraine, under natural conditions, the level of ammonia in groundwater does not exceed $0.2 \mathrm{mg} / \mathrm{dm}^{3}$. In layers with humic substances, the concentration of ammonia can reach $3 \mathrm{mg} / \mathrm{dm}^{3}$. For surface waters, the normal ammonia level does not exceed $12 \mathrm{mg} / \mathrm{dm}^{3}$. The presence of ammonia in high concentrations is an important indicator of fecal contamination of water bodies. At the same time, unpleasant smell and taste of water is observed.

Ammonia is an important source of nitrogen for mammals in the synthesis of amino acids, DNA, RNA, and plays an essential role in the regulation of acid-alkaline reactions, etc. However, in excessive concentrations, it has a toxic effect on aquatic flora and fauna. Increased ammonium content in water objects leads to a reduction in the number of fish in them due to a decrease in the ability of hemoglobin to bind oxygen, resulting in fish suffocation. Moreover, exceeding the level of ammonia in the water leads to ecological instability of the whole ecosystem. As the quantity of nitrogen-sensitive species decreases, functional connections between all parts of the ecosystem are collapsed, that leads to a violation 
of its self-regulation. The reproductive system is especially sensitive to high content of nitrogencontaining compounds and lethal mutations and various alterations in chromosomes are taken place at the genetic level.

The permissible concentration of ammonia in drinking water is $0.5 \mathrm{mg} / \mathrm{dm}^{3}$ - this is the sanitarytoxicological limit of harm to human health. For bottled water, this value is even tighter; it should not exceed $0.1 \mathrm{mg} / \mathrm{dm}^{3}$.

High levels of ammonia are also hazardous to industrial waters. For example, an excess of ammonia in a water vapor in the presence of oxygen increases the process of corrosion of copper-bearing alloys of structures of heat exchangers, which adversely affects the stability of their functioning. Therefore, the concentration of ammonia in the device of heating networks should not exceed $10 \mathrm{mg} / \mathrm{dm}^{3}$ and $5 \mathrm{mg} / \mathrm{dm}^{3}$ in softened and in desalinated water, respectively.

According to the legislation of Ukraine, enterprises are required to monitor the quantity and quality of wastewater discharged to the city sewage systems. Acceptable nitrogen concentrations in water are given in Table 1.

The method of water treatment from ammonium ions depends on the total productivity of the water treatment system, the quality of the initial water (ammonium concentration and the content of other impurities), the requirements for the quality of purified water, the cost of operation, the availability of free areas for installation. The most common methods of water purification from ammonium nitrogen are ion exchange, sorption, reagent treatment, oxidation, reverse osmosis, and biological methods.

The method of removing ammoniacal nitrogen on strongly acidic cation exchangers allows to achieve high purification productivity at the concentrations of pollutant up to $1 \mathrm{mg} / \mathrm{dm}^{3}$ (Malovanyy et al., 2013; Sica et al., 2014). However, the rate of flow and the reduction of ammonium concentration in treated water significantly depend on its composition and limited with the values of general stiffness, concentrations of sodium and potassium ions due to the selectivity of strongly acidic cations in relation to ammonium ions.

The method of sorption of ammonium on natural zeolite allows one to achieve high productivity in removing ammonia nitrogen with concentrations up to $10 \mathrm{mg} / \mathrm{dm}^{3}$ (Widiastuti et al., 2011; Yusof et al., 2010). In the case of clinoptilolite, significant change in the chemical composition of water is not observed. Despite the slowness of the sorption process, the low exchange capacity of the sorbent and high operating costs, the method can be quite attractive for local water purification systems. However, in conditions of an industrial scale, this method is economically disadvantageous due to low capacity, high costs of regeneration and low efficiency in dynamic conditions.

Reagent methods can be used effectively only in the treatment of sewages with high ammonia concentrations (Ratel and Hemangi, 2014; Escudero et al., 2015). One of the most attractive reagent methods is treatment of contaminated water with magnesium compounds (Huang et al., 2010; Tulaydan et al., 2017). However, this process is accompanied by significant reagent consumption and results in secondary pollution of water.

The method of water purification from ammonium ions using active chlorine is quite effective and allows one to remove high ammonia nitrogen concentrations. The use of the method is limited by the need for constant monitoring of the composition of water and the content of chloroorganic compounds in it. At the same time, water filtering through activated carbon is also required. Moreover, it should be noticed that bottled water should not be treated with active chlorine. Other oxidizing agents $\left(\mathrm{O}_{2}, \mathrm{O}_{3}, \mathrm{KMnO}_{4}, \mathrm{NH}_{2} \mathrm{Cl}\right)$ are less effective in ammonia oxidation processes.

The purification of water from ammonium ions by the method of reverse osmosis allows to

Table 1. Acceptable values of nitrogen concentrations in sewage and water objects

\begin{tabular}{|c|c|c|c|c|}
\hline \multirow{2}{*}{ Substance } & Class of danger & $\begin{array}{c}\text { Maximum permissible } \\
\text { concentration in sewage } \\
\text { before biological treatment } \\
\left(\mathrm{mg} / \mathrm{dm}^{3}\right)\end{array}$ & $\begin{array}{c}\text { Maximum permissible concentration in water objects, } \\
\left(\mathrm{mg} / \mathrm{dm}^{3}\right)\end{array}$ \\
\cline { 4 - 5 } & & Household and drinking & $\begin{array}{c}\text { Fishing industry water } \\
\text { supply }\end{array}$ \\
\hline $\mathrm{NH}_{4}{ }^{+}$ & 3 & 30.0 & 2.0 & 0.5 \\
\hline $\mathrm{NO}_{3}{ }^{-}$ & 3 & 45.0 & 45.0 & 40.0 \\
\hline $\mathrm{NO}_{2}{ }^{-}$ & 2 & 3.3 & 3.3 & 0.08 \\
\hline
\end{tabular}


remove ammonium from water solutions with the concentrations of $1-2 \mathrm{mg} / \mathrm{dm}^{3}$, the residual ammonium content remains in the range of 0.1 $\mathrm{mg} / \mathrm{dm}^{3}$. The disadvantages of reverse osmosis purification include: thorough pre-preparation of water, deep desalting of water, large volumes of concentrates are formed, high capital expenditures are needed, and the need for artificial mineralization of permeate is present.

Biological methods have proven themselves well in purifying sewages at the presence of nutrients and microelement (Nozhevnikova et al., 2012; Mousavi et al., 2017; Han et al., 2012; Jung-Jeng et al., 2014; Malovanyy et al., 2014). However, these methods are ineffective in purifying natural waters with low ammonium concentrations. In addition, biological methods require a long processing time, subsequent secondary treatment and disinfection of water.

On the basis of analysis of modern scientific publications, it is possible to conclude that there are very few effective methods for removal of nitrogen-containing compounds from water.

Based on the results of previous studies (Petrichenko et al., 2018; Gomelya et al., 2018), it is known that oxidation of ammonium ions in an anodic chamber of a two-chamber electrolyzer results in a significant acidification of solutions. Additional research should be conducted, taking into account the alkalinity of water.

The aim of this research work was to study the processes of electrochemical oxidation of ammonia in the anolyte of a two-chamber electrolyzer, depending on the composition of the initial solution of anolyte and catholyte, current density and electrolysis time.

\section{MATERIALS AND METHODS}

In this work, a two-chamber electrolyzer with anion exchange membrane MA-41 (Ukraine, Russia) was used. Scheme of electrolyzer is presented in Figure 1. Stainless steel cathode (cathode surface $-0.12 \mathrm{dm}^{2}$ ) and titanium anode coated with ruthenium oxide (anode surface $0.12 \mathrm{dm}^{2}$ ) was used during work. The distance between electrodes was $8 \mathrm{~cm}$; current density was in the range $86.2-172.4 \mathrm{~A} / \mathrm{m}^{2}$.

Model solutions of ammonia were placed to the anode chamber. Distilled and tap water $\left(\left[\mathrm{Cl}^{-}\right]=17 \mathrm{mg} / \mathrm{dm}^{3} ;\left[\mathrm{SO}_{4}{ }^{2-}\right]=15 \mathrm{mg} / \mathrm{dm}^{3}\right)$ were used to prepare model solutions of ammonia with

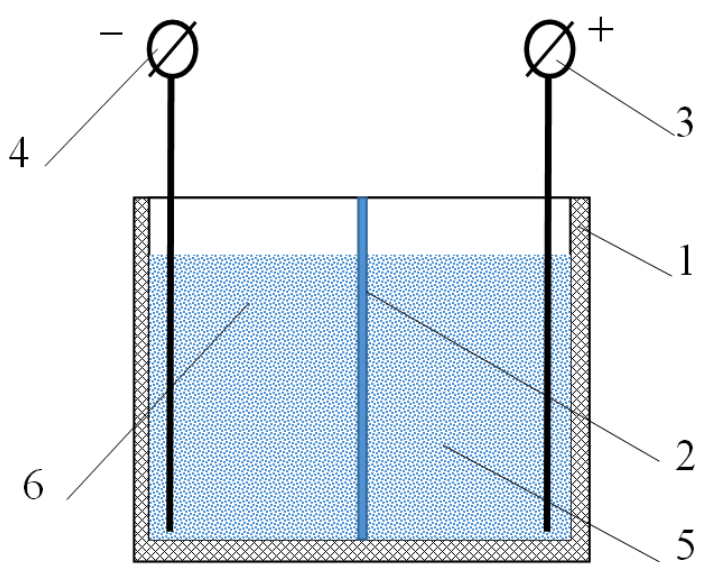

Fig. 1. Scheme of two-chamber electrolyzer: 1 - container; 2 - membrane MA-41; 3 - anode; 4 - cathode; 5 - model solution of ammonia; 6 - alkaline solution

the concentrations $5-50 \mathrm{mg} / \mathrm{dm}^{3}$. The initial $\mathrm{pH}$ value was 8.02-8.95. The concentration of chloride and sulfate ions in the anolyte was $17-100$ and $15-120 \mathrm{mg} / \mathrm{dm}^{3}$, respectively. A $0.05 \mathrm{~N}$ alkaline solution $(\mathrm{NaOH})$ or a mixture of $0.05 \mathrm{~N}$ alkaline solution with chlorides (concentration up to $90 \mathrm{mg} / \mathrm{dm}^{3}$ ) or a mixture with sulfates (concentrations up to $100 \mathrm{mg} / \mathrm{dm}^{3}$ ) was placed to the cathode chamber.

The residual concentration of ammonium ions and $\mathrm{pH}$ in anolyte was determined at regular intervals; in some studies, the content of nitrates was determined. All water quality indicators were determined according to the methods described in (Novikov 1990).

Current output $(B, \%)$ was calculated by the formula:

$$
B=\left(m_{a} / m_{T}\right) \cdot 100
$$

where: $q_{r}$ - the amount of electricity that was actually spent on the transfer of gramequivalent of the substance;

$q_{T}$ - theoretically calculated amount of electricity that is necessary for the transfer of gram-equivalent of substance;

$m_{a}-$ the amount of the actual transferred substance, $\mathrm{g}$;

$m_{T}$ - the theoretically determined amount of the transferred substance, $g$.

The theoretical amount of the transferred substance and actual amount of the transferred substance was determined by the formulas (1) and (2):

$$
\begin{gathered}
m_{T}=K_{E} \cdot I \cdot t \\
m_{a}=V_{s} \cdot\left(C_{i}-C_{e}\right)
\end{gathered}
$$


where: $K_{E}$ - electrochemical equivalent $(0.03731$

[g-eqv/(A-h)]);

$I$ - current intensity, A;

$t$ - time, h;

$V_{s}$ - volume of solution, $\left.\mathrm{dm}^{3}\right)$;

$C_{i}^{s}-$ initial concentration of ions in solution, $\mathrm{g} / \mathrm{dm}^{3}$;

$C_{e}$ - concentration of ions in the solution after electrolysis, $\mathrm{g} / \mathrm{dm}^{3}$.

Specific electrical conductivity $\left(\chi, \mathrm{Om}^{-1} \cdot \mathrm{m}^{-1}\right)$ was calculated as:

$$
\chi=(I \cdot l) /(U \cdot S)
$$

where: $I$ - current intensity, A;

$I$ - distance between electrodes, $\mathrm{m}$;

$U$ - voltage, V; $S$ - anode surface, $\mathrm{m}^{2}$.

\section{RESULTS AND DISCUSSION}

\section{Influence of ammonia ions concentration and time on efficiency of electrolysis}

To study the effect of time on ammonia ions concentration and on $\mathrm{pH}$, the electrolysis at current density of $86.2 \mathrm{~A} / \mathrm{m}^{2}$ of solutions with concentration of $\mathrm{NH}_{4} \mathrm{OH} 5,15$ and $30 \mathrm{mg} / \mathrm{dm}^{3}$ in tap water at $\mathrm{pH} 5.7$ was carried out and results are given in Figure 2. As can be seen, electrolysis leads to almost linear change in the content of ammonium ions in an aqueous solution. The time of removal depends on ions concentration. While removal of ammonium ions from solution with the concentration of $5 \mathrm{mg} / \mathrm{dm}^{3}$ occurs in 30 minutes, the oxidation of the same ions with the concentration $30 \mathrm{mg} / \mathrm{dm}^{3}$ takes place in two hours. For all investigated concentrations, a decrease in the values of $\mathrm{pH}$ during electrolysis is observed, probably due to the formation of acidic products as a result of nitrogen oxidation.

It is known that the removal of protons at the anode during the oxidation of water, or acidic products during the transformation of active chlorine, obtained by oxidation of chlorides, is accompanied by the formation of an appropriate amount of hydroxide anions on the cathode. Filling the cathode chamber with $0.05 \mathrm{~N} \mathrm{NaOH}$ solution provides effective diffusion of hydroxide ions into the anode region. Therefore, in this case, acidification of anolyte can be explained by the formation of nitrogen dioxide and nitrates, as evidenced by the data given in Table 2 .

The effect of time on the current output and the electrical conductivity during electrolysis was investigated and the results are given in Figure 3.

As can be seen, the increase in both parameters for is observed (Fig. 3). The higher the concentration of ammonium ions in the initial solution, the higher is the value of the current output and the electrical conductivity.

\section{Influence of chlorides concentration in model solution on efficiency of electrolysis}

The influence of chlorides on the intensity of oxidation of ammonia was determined using a solution of ammonia with concentration of $50 \mathrm{mg} / \mathrm{dm}^{3}$ in tap water. Increasing the concentration of chlorides from $17 \mathrm{mg} / \mathrm{dm}^{3}$ (tap water) to 50 and $100 \mathrm{mg} / \mathrm{dm}^{3}$ leads to a reduction in the time for

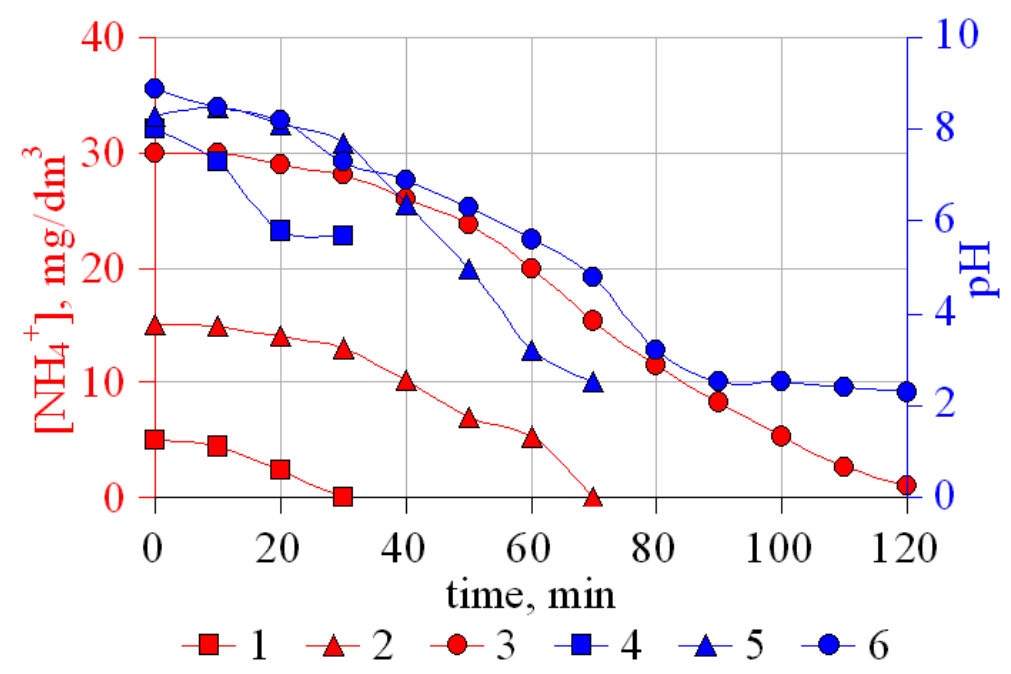

Fig. 2. The effect of time of electrolysis in a two-chamber electrolyzer on ammonia ions concentration $(1,2,3)$ and on $\mathrm{pH}$ at the different initial concentration of $\mathrm{NH}_{4} \mathrm{OH}: 1,4-5 \mathrm{mg} / \mathrm{dm}^{3} ; 2,5-15 \mathrm{mg} / \mathrm{dm}^{3} ; 3,6-5 \mathrm{mg} / \mathrm{dm}$ 
Table 2. Changes in the concentration of ammonium and nitrates as a result of ammonium oxidation in a twochamber electrolyzer (MA-41 membrane) prepared on tap water $\left(\left[\mathrm{Cl}^{-}\right]=17 \mathrm{mg} / \mathrm{dm}^{3} ;\left[\mathrm{SO}_{4}{ }^{2-}\right]=15 \mathrm{mg} / \mathrm{dm}^{3}\right)$ at different initial concentrations of $\mathrm{NH}_{4} \mathrm{OH}$ in anolyte and chlorides in catholyte (in presence of $0.05 \mathrm{~N} \mathrm{NaOH}$ )

\begin{tabular}{|c|c|c|c|c|c|c|c|c|}
\hline \multirow{2}{*}{$\begin{array}{c}\mathrm{t} \\
(\mathrm{min})\end{array}$} & \multirow{2}{*}{$\begin{array}{c}\text { I } \\
(\mathrm{A})\end{array}$} & \multirow{2}{*}{$\begin{array}{l}{[\mathrm{Cl}] \text { in catholyte }} \\
\left(\mathrm{mg} / \mathrm{dm}^{3}\right)\end{array}$} & \multicolumn{3}{|c|}{ Concentration in anolyte $\left(\mathrm{mg} / \mathrm{dm}^{3}\right)$} & \multirow{2}{*}{$\begin{array}{c}\mathrm{m}_{\mathrm{T}} \\
\left(\mathrm{NO}_{3}^{-}\right) \\
(\mathrm{mg})\end{array}$} & \multirow{2}{*}{$\begin{array}{c}\mathrm{m}_{\mathrm{a}} \\
\left(\mathrm{NO}_{3}^{-}\right) \\
(\mathrm{mg})\end{array}$} & \multirow{2}{*}{$\mathrm{B}(\%)$} \\
\hline & & & {$\left[\mathrm{NH}_{4}{ }^{+}\right]_{\text {initial }}$} & {$\left[\mathrm{NH}_{4}^{+}\right]_{\text {final }}$} & {$\left[\mathrm{NO}_{3}^{-}\right]$} & & & \\
\hline 120 & 0.1 & - & 30 & 1.0 & 66.0 & 6.99 & 4.62 & 66.1 \\
\hline 270 & 0.2 & - & 50 & 0 & 118.0 & 12.06 & 8.26 & 68.5 \\
\hline 210 & 0.2 & - & 50 & 8.0 & 145.0 & 10.13 & 10.13 & 100.0 \\
\hline 210 & 0.2 & 10 & 50 & 8.0 & 145.0 & 10.13 & 10.13 & 100.0 \\
\hline 210 & 0.2 & 20 & 50 & 6.0 & 151.2 & 10.61 & 10.58 & 99.8 \\
\hline 240 & 0.2 & 50 & 50 & 0 & 172.0 & 12.06 & 12.04 & 99.9 \\
\hline
\end{tabular}

complete oxidation of ammonia to 2 hours (Fig. 4). Current output rises to almost $15.3 \%$ (Fig. 5).

As can be seen, reduction of electricity consumption with increasing chloride content in the solution is observed. The same results were obtained by other authors (Petrichenko et al., 2018; Gomelya et al., 2018).

\section{Influence of chlorides concentration in the cathode region on efficiency of electrolysis}

To study the effect of chlorides concentration in the cathode region on ammonia ions concentration and on $\mathrm{pH}$ as well as the electricity consumption on ammonium oxidation, the electrolysis at current density of $172,4 \mathrm{~A} / \mathrm{m}^{2}$ of solutions of $\mathrm{NH}_{4} \mathrm{OH}$ with the concentration $50 \mathrm{mg} / \mathrm{dm}^{3}$ in tap water was carried out and results are given in Figure 6 and Table 3.

From the analysis of the results presented in Figure 6 and Table 3, it is evident that at the presence of chlorides at $17 \mathrm{mg} / \mathrm{dm}^{3}$ in the cathode region, the oxidation of ammonia is less effective in comparison with oxidation of ammonia at the presence of chlorides with higher concentrations. Complete oxidation of ammonia occurred at the concentration of chlorides in the catholyte at 50 and $90 \mathrm{mg} / \mathrm{dm}^{3}$.

With an increase in the concentration of chlorides in the catholyte from 10 to $90 \mathrm{mg} / \mathrm{dm}^{3}$, the current output of oxidized nitrogen increased from $1.77-5.89 \%$ to $5.52-8.83 \%$ (Fig. 7). It should be noted that the electrical conductivity of the system, as in all previous cases, was low.

\section{Influence of sulfates concentration in the anode and cathode region on efficiency of electrolysis}

Investigation of the dependence of the efficiency of ammonium oxidation in a solution of distilled and tap water on sulfates concentration in

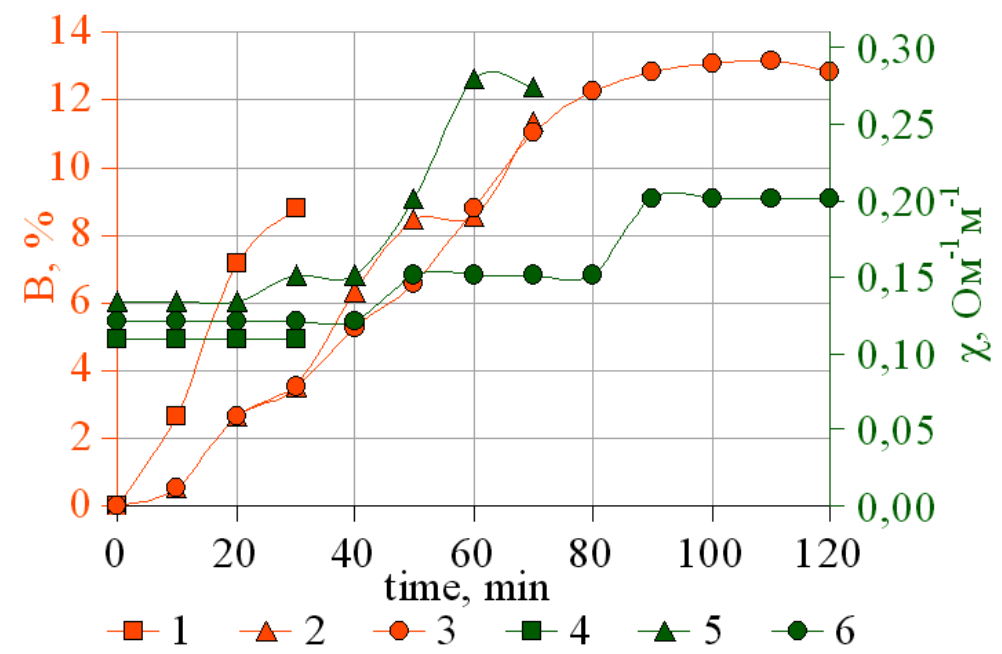

Fig. 3. The effect of time of electrolysis in a two-chamber electrolyzer on the current output $(1,2,3)$ and specific conductivity $(4,5,6)$ during ammonium oxidation at different initial concentrations of $\mathrm{NH}_{4} \mathrm{OH}: 1,4-5 \mathrm{mg} / \mathrm{dm}^{3} ; 2,5-15 \mathrm{mg} / \mathrm{dm}^{3} ; 3,6-5 \mathrm{mg} / \mathrm{dm}^{3}$ 


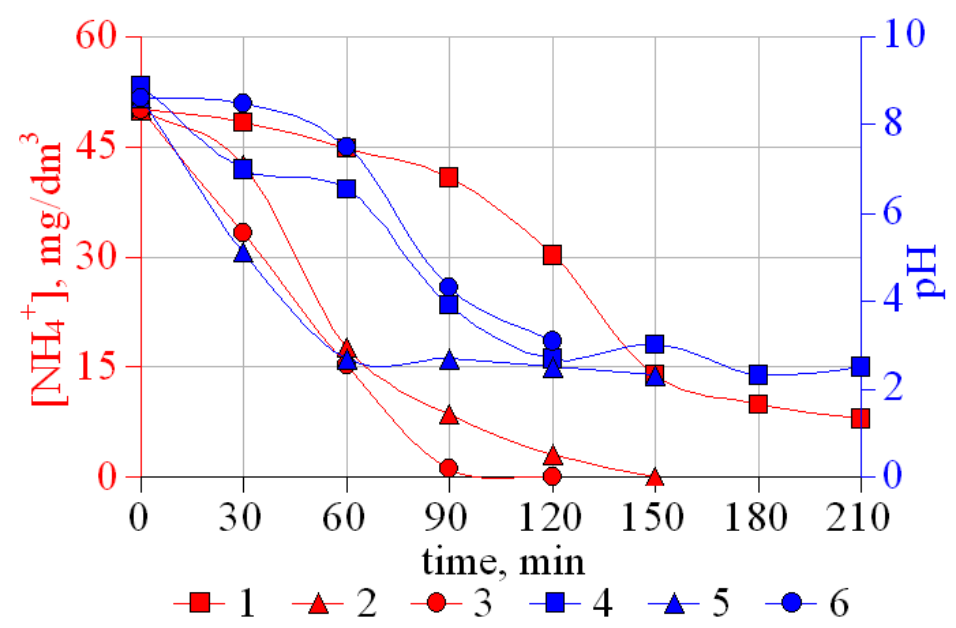

Fig. 4. Reduction of the concentration of ammonium $(1 ; 2 ; 3)$ and $\mathrm{pH}(4 ; 5 ; 6)$ in anolyte of a two-chamber electrolyzer with electrolysis time at a current density of $172.4 \mathrm{~A} / \mathrm{m}^{2}$, at the different concentration of chlorides: $1,4-17 \mathrm{mg} / \mathrm{dm}^{3} ; 2,5-50 \mathrm{mg} / \mathrm{dm}^{3} ; 3,6-100 \mathrm{mg} / \mathrm{dm}^{3}$

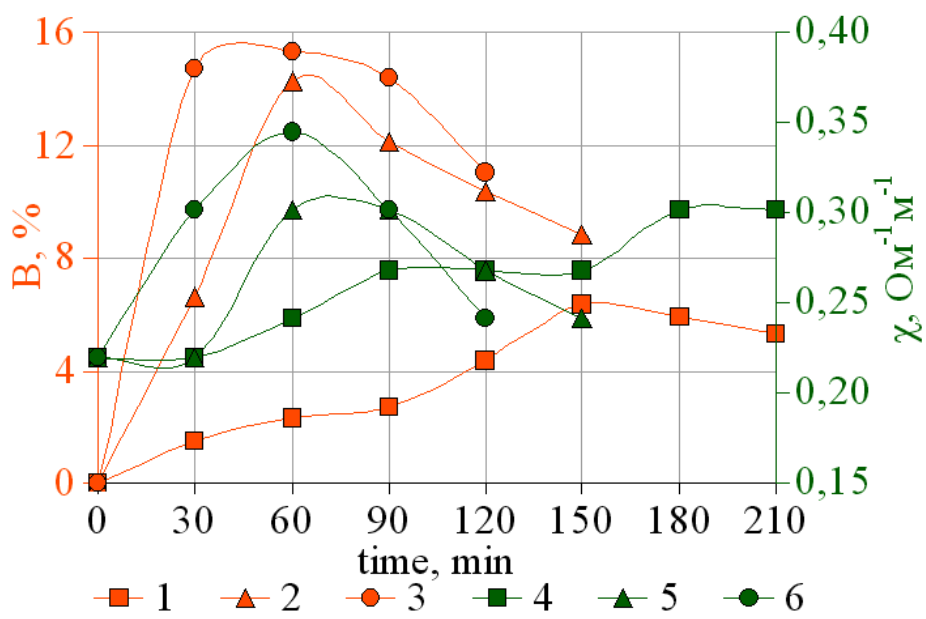

Fig. 5. Reduction of the current output $(1 ; 2 ; 3)$ and specific conductivity $(4 ; 5 ; 6)$ with electrolysis time at a current density of $172.4 \mathrm{~A} / \mathrm{m}^{2}$, at the different concentration of chlorides: $1,4-17 \mathrm{mg} / \mathrm{dm}^{3} ; 2,5-50 \mathrm{mg} / \mathrm{dm}^{3} ; 3,6-100 \mathrm{mg} / \mathrm{dm}^{3}$

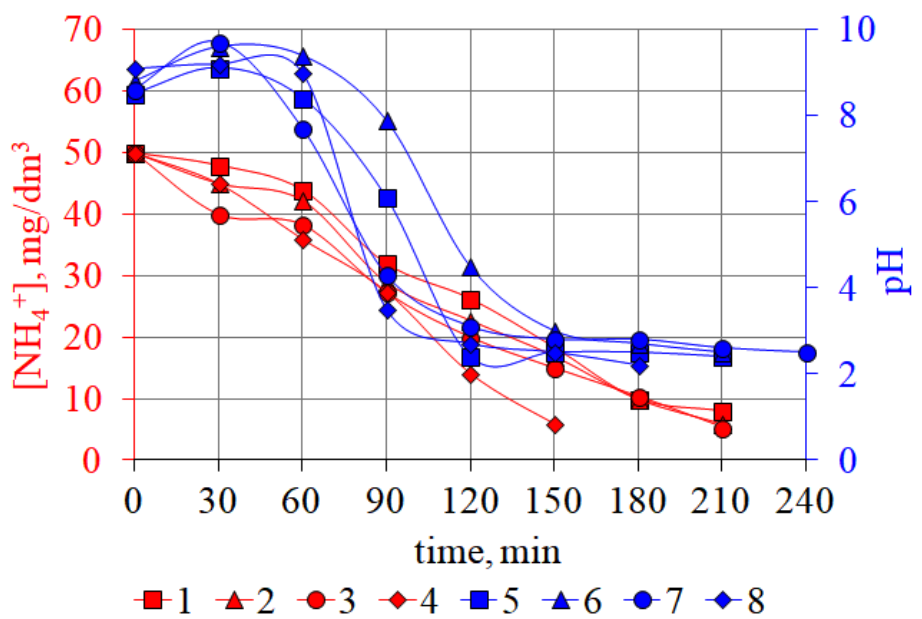

Fig. 6. Reduction of the ammonium concentration $(1 ; 2 ; 3 ; 4)$ and $\mathrm{pH}(5 ; 6 ; 7 ; 8)$ with electrolysis time at the different concentration of chlorides in the cathode region: $1,5-10 \mathrm{mg} / \mathrm{dm}^{3} ; 2,6-20 \mathrm{mg} / \mathrm{dm}^{3} ; 3,7-50 \mathrm{mg} / \mathrm{dm}^{3} ; 4,8-90 \mathrm{mg} / \mathrm{dm}$ 


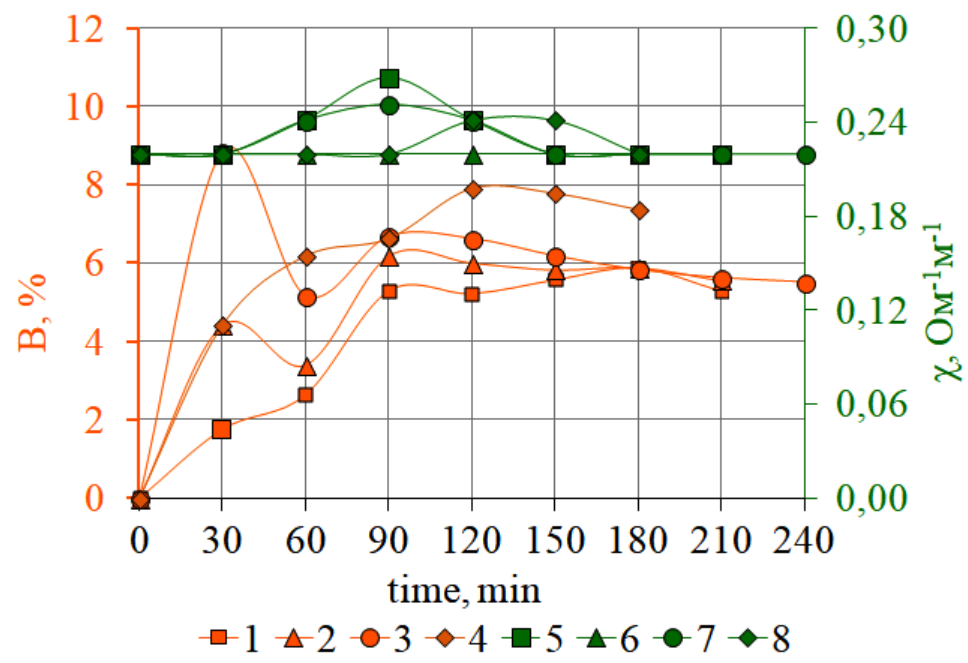

Fig. 7. The dependence of the current output at oxidation of ammonia $(1 ; 2 ; 3 ; 4)$ and specific conductivity $(5 ; 6 ; 7 ; 8)$ from the time of electrolysis at the different concentration of chlorides in the cathode region: $1,5-10 \mathrm{mg} / \mathrm{dm}^{3} ; 2,6-20 \mathrm{mg} / \mathrm{dm}^{3} ; 3,7-50 \mathrm{mg} / \mathrm{dm}^{3} ; 4,8-90 \mathrm{mg} / \mathrm{dm}^{3}$

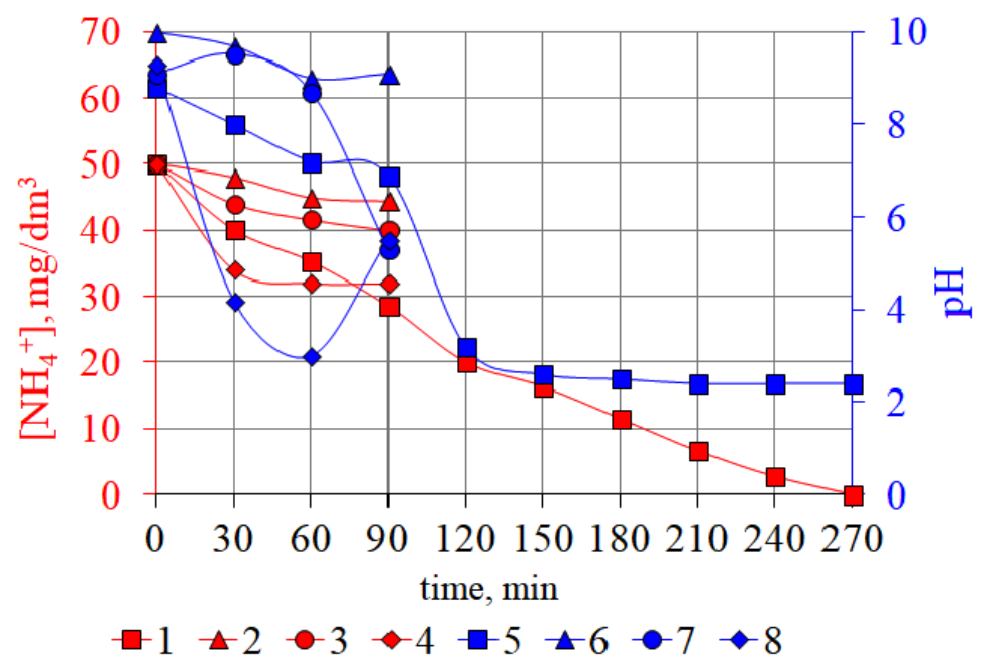

Fig. 8. The decrease of the ammonium concentration $(1 ; 2 ; 3 ; 4)$ and the $\mathrm{pH}$ value $(5 ; 6 ; 7 ; 8)$ in anolyte of a two-chamber electrolyzer with electrolysis time at a current density of $86.2 \mathrm{~A} / \mathrm{m}^{2}(2 ; 3$; $4 ; 6 ; 7 ; 8)$ and $172.4 \mathrm{~A} / \mathrm{m}^{2}(1 ; 5)$; at an initial concentration of $\mathrm{NH}_{4} \mathrm{OH} 50 \mathrm{mg} / \mathrm{dm}^{3}$ in a solution on distilled water $(2 ; 6)$ and tap water $(1 ; 3 ; 4 ; 5 ; 7 ; 8)$ and sulfate concentrations in the anode region, $\mathrm{mg} / \mathrm{dm}^{3}: 30(1 ; 5), 100(2 ; 6), 120(3 ; 7)$ and in the cathode region $100 \mathrm{mg} / \mathrm{dm}^{3}(4 ; 8)$.

Table 3. The dependence of electricity consumption on ammonium oxidation in tap water with chlorides concentration 17 and $100 \mathrm{mg} / \mathrm{dm}^{3}$ from the time of electrolysis

\begin{tabular}{|c|c|c|}
\hline \multirow{2}{*}{ Time, $\min$} & \multicolumn{2}{|c|}{ Electricity consumption $(\mathrm{kW} \cdot \mathrm{h} / \mathrm{g}$-eqv) } \\
\cline { 2 - 3 } & \multicolumn{2}{|c|}{$\left[\mathrm{NH}_{4}^{+}\right] /[\mathrm{Cl}]\left(\mathrm{mg} / \mathrm{dm}^{3}\right)$} \\
\cline { 2 - 3 } & $50 / 17$ & $50 / 100$ \\
\hline 30 & 98.21 & 7.27 \\
\hline 60 & 58.38 & 6.12 \\
\hline 90 & 44.55 & 7.43 \\
\hline 120 & 27.74 & 12.14 \\
\hline 150 & 18.97 & - \\
\hline
\end{tabular}

Table 4. The dependence of electricity consumption on ammonium oxidation in tap water from the composition of the solution and time of electrolysis

\begin{tabular}{|c|c|c|}
\hline \multirow{2}{*}{ Time, min } & \multicolumn{2}{|c|}{ Electricity consumption $(\mathrm{kW} \cdot \mathrm{h} / \mathrm{g}$-eqv) } \\
\cline { 2 - 3 } & \multicolumn{2}{|c|}{$\left[\mathrm{NH}_{4}{ }^{+}\right] /\left[\mathrm{SO}_{4}{ }^{2-}\right]\left(\mathrm{mg} / \mathrm{dm}^{3}\right)$} \\
\hline & $50 / 30$ & $50 / 100$ \\
\hline 30 & 16.70 & 22.77 \\
\hline 60 & 22.56 & 18.21 \\
\hline 90 & 21.18 & 24.84 \\
\hline 120 & 18.21 & - \\
\hline 150 & 22.52 & - \\
\hline
\end{tabular}




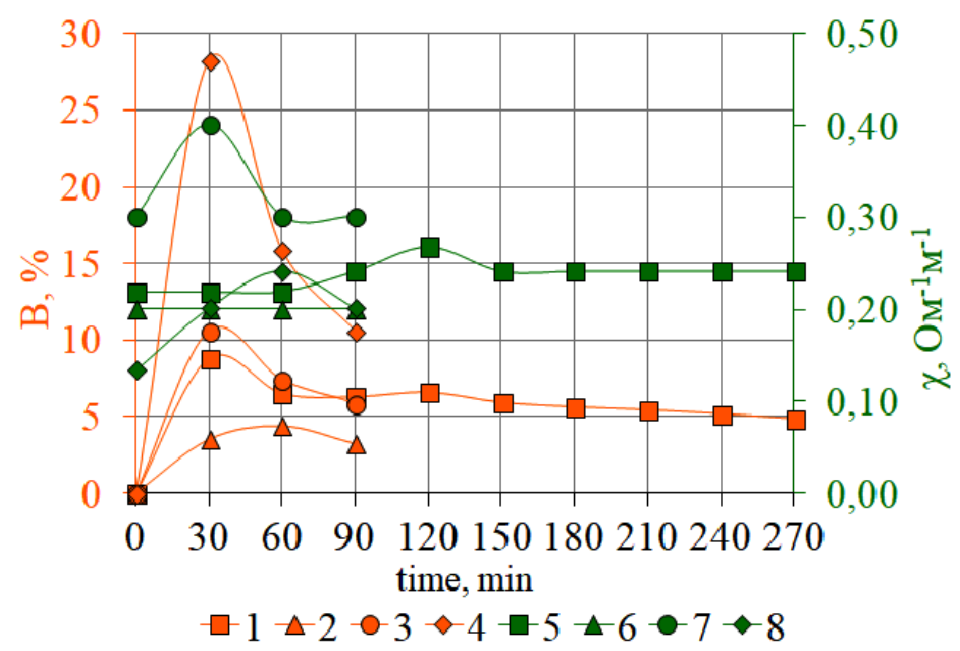

Fig. 9. The decrease of current output $(1 ; 2 ; 3 ; 4)$ and specific conductivity $(5 ; 6 ; 7 ; 8)$ in anolyte of a two-chamber electrolyzer with electrolysis time at a current density of $86.2 \mathrm{~A} / \mathrm{m}^{2}(2 ; 3$; $4 ; 6 ; 7 ; 8)$ and $172.4 \mathrm{~A} / \mathrm{m}^{2}(1 ; 5)$; at an initial concentration of $\mathrm{NH} 4 \mathrm{OH} 50 \mathrm{mg} / \mathrm{dm}^{3}$ in a solution on distilled water $(2 ; 6)$ and tap water $(1 ; 3 ; 4 ; 5 ; 7 ; 8)$ and sulfate concentrations in the anode region, $\mathrm{mg} / \mathrm{dm}^{3}: 30(1 ; 5), 100(2 ; 6), 120(3 ; 7)$ and in the cathode region $100 \mathrm{mg} / \mathrm{dm}^{3}(4 ; 8)$

catholyte and anolyte were carried out at current density of 86.2 and $172.4 \mathrm{~A} / \mathrm{m}^{2}$. The use of sulfates in the cathode and anode region contributes to a significant deceleration of the ammonia oxidation process (Fig. 8) and to the increase in the electric energy consumption (Table 4). Complete oxidation of ammonium takes place in 4.5 hours at a minimum concentration of sulfates in the catholyte $\left(30 \mathrm{mg} / \mathrm{dm}^{3}\right)$. In all other cases, the ammonium content decreases only to $5-16 \mathrm{mg} / \mathrm{dm}^{3}$ during 1.5 hours at a current density of $86.2 \mathrm{~A} / \mathrm{m}^{2}$. At the same time, current output of nitrogen oxidation reduces to $1.84-3.31 \%$ (Fig. 9).

The results obtained can be explained by a significant loss of electricity for oxidation of sulfates to persulfates, which are quite passive to ammonium ions, therefore their formation causes a slowdown in the oxidation process of ammonia. The only positive aspect observed at the presence of sodium sulfate to anolyte, was the increase the electrical conductivity of the solution (Fig. 9).

\section{CONCLUSIONS}

1. Oxidation of ammonia in anodic chamber of a two-chamber electrolyzer with anion exchange membrane MA-41 passes effectively and is accompanied by a decrease in $\mathrm{pH}$, depending on the initial concentration of ammonia in water. Acidification of the solution occurs due to the formation of acidic products in the oxidation of nitrogen.

2. The use of chloride ions in the catholyte practically does not accelerate the process of oxidation of ammonia. However, chloride present in anolyte is practically linearly catalyze its oxidation: the higher the concentration of chlorides in the anolyte, the more significant the by current output of the substance.

3. Sulphate ions both in anolyte and catholyte slow down the process of oxidation of ammonia, which is explained by the oxidation of sulfates to persulfates and is accompanied by an increase in electricity consumption

\section{REFERENCES}

1. Escudero A., Blanco F., Lacalle A., Pinto M. 2015. Struvite precipitation for ammonium removal from anaerobically treated effluents. Journal of Environmental Chemical Engineering, 3(1), 413-419.

2. Gomelya M.D, Petrichenko A.I, Shabliy T.O. 2018. Removal of ammonium ions from water by electrolysis Vcheni zapysky Tavriiskoho natsionalnoho universytetu imeni V.I. Vernadskoho. Seriia: Tekhnichni nauky, 29(68), 99-105.

3. Han M., Zhao Z., Cui F., Gao W., Liu J., Zeng Z.Q. 2012. Pretreatment of contaminated raw water by a novel double-layer biological aerated filter for drinking water treatment. Desalination and Water Treatment, 37(1), 308-314. 
4. Huang H., Xiao X., Yang L., Yan B. 2010. Removal of ammonium as struvite using magnesite as a source of magnesium ions. Water Practice and Technology, 5(1), 1-9.

5. Jung-Jeng S., Yuan-Chie C., Shun-Ming H. 2014. Ammonium reduction from piggery wastewater using immobilized ammonium-reducing bacteria with a full-scale sequencing batch reactor on farm. Water Science and Technology, 69(4), 840-846.

6. Malovanyy A., Plaza E., Trela J., Malovanyy M. 2014. Combination of ion exchange and partial nitritation/Anammox process for ammonium removal from mainstream municipal wastewater. Water Science and Technology, 70(1), 144-151.

7. Malovanyy A., Sakalova H., Tulaydan Y., Yatchyshyn N., Plaza E., Malovanyy M. 2013. Concentration of ammonium from municipal wastewater using ion exchange process. Desalination, 329, 93-102.

8. Mousavi S. A., Ibrahim S., Aroua M.K. 2017. Effect of carbon source on acclimatization of nitrifying bacteria to achieve high-rate partial nitrification of wastewater with high ammonium concentration. Applied Water Science, 7(1), 165-173.

9. Novikov U.V. 1990. Water quality testing methods. Medicine, Moscow. (In Russian).

10. Nozhevnikova A.N., Simankova M.V., Litti Y.V. 2012. Application of the microbial process of anaerobic ammonium oxidation (ANAMMOX) in biotechnological wastewater treatment. Applied Biochemistry and Microbiology, 48(8), 667-684.

11. Patel I.A., Desai H.H. 2014. Ammonium Removal from Landfill Leachate by Chemical Precipitation. International Journal of Innovative Research and Development, 3(7), 116-126.

12. Petrichenko A., Makarenko I., Radovenchyk I., Shabliy T. 2018. Removal of ammonium ions from water by electrolysis. Easten-Europen journal of Enterprise Technologies, 4/6(94), 26-34.

13. Sica M., Duta A., Teodosiu C., Draghici C. 2014. Thermodynamic and kinetic study on ammonium removal from a synthetic water solution using ion exchange resin. Clean Technologies and Environmental Policy, 16(2), 351-359.

14. Tulaydan Y., Malovanyy M., Kochubei V., Sakalova H. 2017. Treatment of high-strength wastewater from ammonium and phosphate ions with the obtaining of struvite. Chemistry and Chemical Technology, 11(4), 463-468.

15. Widiastuti N., Wu H., Ang H.M., Zhang D. 2011. Removal of ammonium from greywater using natural zeolite. Desalination, 277(1), 15-23.

16. Yusof A.M., Keat L.K., Ibrahim Z., Majid Z.A., Nizam N.A. 2010. Kinetic and equilibrium studies of the removal of ammonium ions from aqueous solution by rice husk ash-synthesized zeolite Y and powdered and granulated forms of mordenite. Journal of Hazardous Materials, 174(1), 380-385. 